\title{
The effect of the characteristics of pregnant women and stress on the psychological well-being
}

\author{
Mariah Ulfah $^{1 *}$, Suryo Ediyono², Ita Apriliyani ${ }^{3}$ \\ ${ }^{1,3}$ Faculty of Health, Undergraduate Nursing Study Program, Universitas Harapan Bangsa \\ ${ }^{2}$ Faculty of Cultural Studies Universitas Sebelas Maret \\ 1'Mariahulfah@uhb.ac.id*; diyonosuryo@staff.uns.ac.id; ${ }^{3}$ Itaapriliyani@uhb.ac.id \\ *corresponding author
}

Submission date: 18 Juli 2021, Receipt date: 20 Agustus 2021, Publication date: 1 November 2021

\begin{abstract}
Introduction: Pregnancy affects physical and psychological changes. Especially during the Covid-19 period, there is a possibility of stress. The health problems of pregnant women that are not handled optimally are related to psychological problems, this will affect the success of the postpartum period, including during the breastfeeding process. Therefore, it is necessary to conduct research related to stress conditions in pregnant women which will affect the psychological well-being of pregnant women. Objective: to determine the characteristics of the mother and the stress of pregnant women affects psychological well-being. Method: observational analysis with a cross-sectional design. The research population of pregnant women in the antenatal class with a sample of 60 people with data collection techniques using systematic random sampling. The results showed: there was an effect of maternal characteristics (age, gestational age, parity) on psychological well-being. And there is the effect of stress on psychological well-being with a $p$ value of 0.000 .
\end{abstract}

Keywords: pregnancy; psychological wellbeing; stress

\section{INTRODUCTION}

Pregnancy affects psychological, social aspects both positively and negatively, where these conditions affect mental well-being such as depression and anxiety (Parfitt \& Ayers, 2014). Constantly high demands and stress can cause psychological, physical, and behavioral health problems (Lestari \& Widyawati, 2016). Stress can be cited as an important factor in determining psychological health and well-being and can harm both (Sunday et al., 2017). Individuals who experience continuous conflict and stress gradually affect their psychological well-being (Saxbe 2018). Individuals whose psychological well-being is fulfilled tend to view their lives positively, are able to develop themselves optimally and more optimally and have goals in life (Mahmudah et al., 2016).

Stress affects the role of parents during pregnancy (Choiriyah, 2016). Longitudinal research on parental self-efficacy on 235 primiparous women aged 21-43 years who perceived stress, depression, and anxiety. In this study perinatal stress was associated with parental self-efficacy. Wernand and colleagues examined parental selfefficacy and depression and anxiety in 533 primiparous women, finding that psychopathology was greater in all trimesters of pregnancy (Brunton et al., 2020), in 
addition to a prospective cohort study assessing depressive symptoms and associated factors among 838 women who were pregnant for the first time, found that respondents did not experience depression from the third trimester of pregnancy to 12 weeks postpartum, but increased in the first pregnancy, later due to social isolation and due to an unsatisfactory marriage (Abdollahi et al., 2016).

Impact of COVID Pandemic 19 has also led to some changes in behavior patterns, one of which is social distancing. These changes increase psychological problems such as anxiety and depression in the mother during pregnancy (Leonard, 2020), (LópezMorales et al., 2021), (Mofrad et al., 2021). The results of the study found symptoms of anxiety and stress, depression was found in cases when women were not pregnant $5 \%$ and women during pregnancy 8-10\% (Sanadi et al., 2016). Pregnant women are considered as vulnerable subjects who have risk factors for emotional changes and stress because it will have an impact on the mother and fetus, namely poor fetal development, preterm birth and low birth weight babies (LBW). Children with preterm birth or low birth weight are at risk for emotional or cognitive problems, including hyperactivity, anxiety, or language delays (Arisanti, 2021). Support in the transition period will go well, where parents during the transition period really need a lot of support in preparation to become parents so that they can improve psychological well-being (Ramluggun et al., 2020),(Holopainen \& Hakulinen, 2019). Stress that occurs in pregnant women will be at risk in the next process, including the postpartum period and breastfeeding. This is exacerbated if the mother's age is less than 18 years, this age group is at risk for mental disorders, stress, depression and trauma (Nabit et al., 2019), (Sulistiawati \& Pratiwi, 2021). The period of pregnancy is part of the life cycle that requires special attention in the health sector. Pregnant women have the means to share information, namely in antenatal classes, but psychological problems in the health of pregnant women have not been maximally addressed, even though these conditions affect the quality of life of mothers and children. Based on this phenomenon, the researcher wanted to see the effect of maternal characteristics and stress levels of pregnant women on psychological wellbeing.

\section{RESEARCH METHODS}

This study used observational analysis with a cross-sectional design. The research population of pregnant women in the antenatal class with a sample of 60 pregnant women at the Banyumas Regional Health Center with data collection techniques using systematic random sampling (Sugiyono 2018). The variables in this study were: maternal characteristics consisting of; maternal age, gestational age, parity, stress level and psychological well-being. Questionnaires were taken from ryff and DSS (Octaviani et al., 2018). This data uses categorical so that the data is processed using chi square. The measuring instrument used is a standard scale to measure stress levels, namely thescale Depression Anxiety Stress 42 (DASS-42) by Lovibond and Lovibond (1995). DASS-42 is a subjective scale consisting of 42 question items that were formed to measure the negative emotional status of depression, anxiety, and stress (Mubarak et al., 2015).

Measured by the scale "Psychological well-beingThe Ryff scales of Psychological well-beingis" which is the original copyrighted scale from Ryff which has been translated by Hesti (2016) and rearranged by Debbi Radifta Jayafa (2018). This scale consists of six multidimensional aspects of psychological well-being and uses the Likert method totaling 
36 question items with four answer choices, namely STS (very inappropriate), TS (not appropriate), S (appropriate), and SS (very appropriate), consisting of 18 unvaforoble questions and 18 favorable questions (Sesillia, 2020).

This research has been declared to have passed the ethical test with the number: B.LPPM-UHB/585/11/2021, by the research ethics research team at Harapan Bangsa University.

\section{RESULTS AND DISCUSSION}

\section{Research Results}

Most of the respondents were of healthy reproductive age (20-35 years) (75\%) with gestational age entered in the 2 nd trimester $(56.7 \%)$ and were pregnant with more than 1 or multigravida $(51.7 \%)$. In the stress variable, most pregnant women are under moderate stress $(36.7 \%)$, but some are in a very severe stress condition $(15 \%)$, with the highest psychological well-being in the low category $(88.3 \%)$.

Table 1. Characteristics of respondents and research variables $(n=60)$

\begin{tabular}{|c|c|}
\hline Characteristics of & Results \\
\hline $\begin{array}{l}\text { Maternal age } \\
<20 \text { years } \\
20-35 \text { years } \\
>35 \text { years }\end{array}$ & $\begin{array}{l}11(18.3 \%) \\
45(75.0 \%) \\
4(6.7 \%)\end{array}$ \\
\hline $\begin{array}{l}\text { Gestational age } \\
\text { Trimester } 1 \\
\text { Trimester } 2 \\
\text { Trimester } 3\end{array}$ & $\begin{array}{l}7(11.7 \%) \\
34(56.7 \%) \\
19(31.7 \%)\end{array}$ \\
\hline $\begin{array}{l}\text { Pregnancy } \\
\text { Primigravida } \\
\text { Multigravida }\end{array}$ & $\begin{array}{l}29(48.7 \%) \\
31(51.7 \%)\end{array}$ \\
\hline $\begin{array}{l}\text { Stress of pregnant women } \\
\text { Normal } \\
\text { Low } \\
\text { Moderate } \\
\text { Severe } \\
\text { Very severe }\end{array}$ & $\begin{array}{l}3(5.0 \%) \\
7(11.7 \%) \\
22(36.7 \%) \\
19(31.7 \%) \\
9(15.0 \%)\end{array}$ \\
\hline $\begin{array}{l}\text { Psychological well-being } \\
\text { Low } \\
\text { Medium } \\
\text { High }\end{array}$ & $\begin{array}{l}53(88.3 \%) \\
7(11.7 \%) \\
0(0 \%)\end{array}$ \\
\hline
\end{tabular}

Then cross tabulation was performed between maternal characteristics and stress and psychological well-being. The results of the analysis in table 2 show that maternal age affects psychological well-being with a $\mathrm{P}$ value of $0.000<0.005$, gestational age also affects psychological well-being with a $\mathrm{p}$ value of 0.000 , parity affects psychological 
well-being with a $\mathrm{p}$ value of 0.035 , and stress affects psychological well-being with a $\mathrm{p}$ value 0,000

Table 2. Distribution of a cross between the characteristics of the psychological wellbeing

\begin{tabular}{|c|c|c|c|}
\hline variables & \multicolumn{2}{|c|}{ Psychological wellbeing } & $P$ value \\
\hline Characteristics & Low & Medium & \\
\hline $\begin{array}{l}\text { Age } \\
\cdot<20 \text { years } \\
\cdot 20-35 \text { years } \\
\cdot>35 \text { years old }\end{array}$ & $\begin{array}{l}6(10 \% \\
44(73.3 \%) \\
3(5 \%)\end{array}$ & $\begin{array}{l}5(8.3 \%) \\
1(1.67 \%) \\
1(1.67 \%)\end{array}$ & 0.000 \\
\hline $\begin{array}{l}\text { Gestational age } \\
\text { Trimester I } \\
\text { trimester II } \\
\text { trimester III }\end{array}$ & $\begin{array}{l}6(10 \%) \\
30(50 \%) \\
17(28.3 \%)\end{array}$ & $\begin{array}{l}1(1.67 \%) \\
4(6.67 \%) \\
2(3.33 \%)\end{array}$ & 0.000 \\
\hline $\begin{array}{l}\text { Gravida } \\
\text { Primi } \\
\text { Multi } \\
\text { Grande }\end{array}$ & $\begin{array}{l}23(38.3 \%) \\
30(50 \%) \\
0(0 \%)\end{array}$ & $\begin{array}{l}6(10 \%) \\
1(1.67 \% \\
0(0 \%)\end{array}$ & 0.035 \\
\hline $\begin{array}{l}\text { Stress } \\
\cdot \text {. Normal } \\
\cdot \text { Low } \\
\cdot \text { Moderate } \\
\cdot \text { Severe } \\
\cdot \text { Very severe }\end{array}$ & $\begin{array}{l}0(0 \%) \\
3(5 \%) \\
22(36.67 \%) \\
19(31.67 \%) \\
9(15 \%)\end{array}$ & $\begin{array}{l}3(5 \%) \\
4(6.67 \%) \\
0(0 \%) \\
0(0 \%) \\
0(0 \%)\end{array}$ & 0.000 \\
\hline
\end{tabular}

\section{DISCUSSION}

In this study, maternal age affects psychological well-being with a $p$ value of $0.000<0.005$, where low welfare is found in mothers aged 20-35 years of reproductive health of $73.3 \%$. Anyone is susceptible to stress, not limited by age, educational background or work. A survey conducted in America stated that the millennial age group (18-33 years) and generation X (34-47 years) experienced the highest stress levels on average (Saxbe, 2018)

Gestational age also affects psychological well-being with a $\mathrm{p}$ value of 0.000 where low psychological well-being occurs in second trimester pregnant women $(50 \%)$, this is not in accordance with a study conducted in China, based on gestational age, it was found that pregnant women in the first trimester had moderate to severe levels of anxiety (28\%) compared with second and third trimester pregnancies (Zhou et al., 2020). This may be due to past experiences during pregnancy before, being a factor that also affects stress. A longitudinal study by Razurel, Kaiser, Antonietti, Epiney, and Sellenet examining 235 primiparous women aged 21-43 
years found that perinatal stress was associated with parental self-efficacy, so that the more significant stress was, the more ineffective women felt about motherhood. Another study of 533 primiparous women, found that greater psychopathology was associated with less self-efficacy in all trimesters of pregnancy (Brunton et al., 2020), another study of 838 pregnant women who did not experience depression for the first time from the third trimester of pregnancy to 12 weeks postpartum. , and the incidence of depression increases in the first trimester due to unsatisfactory household relationships (Abdollahi et al., 2016).

Parity affects psychological health with a p value of 0.035 , where the low category occurs in pregnant women who are multigravida by $50 \%$. This is consistent with Marta's research, showing that depression rates did not differ between primiparous and multiparous women, or between pre and postpartum assessments. In contrast, after delivery, primiparous women reported higher scores of environmental mastery and selfacceptance than multiparous women. In addition, this process increased from pregnancy to postpartum among primiparous women, and it was seen that scores of all dimensions of psychological well-being among multiparous women were similar. (Marta Bassi, 2017).

From the results of this study it was found that stress affects psychological wellbeing with a $\mathrm{p}$ value of 0.000 , where the lowest welfare occurs in people who are under moderate stress $(36.67 \%)$, even $15 \%$ in the category of severe stress. This is in line with research (Budiarti \& Hanoum, 2019) and (Octaviani et al., 2018) which state that coping stress affects a person's psychological well-being. This stress will also have an impact on individual well-being. Individual levels of well-being are higher when individuals feel less stressed. Individual well-being is also related to mental health conditions. In the view of traditional psychology, a state of well-being and a healthy mental state means describing the condition of the absence of stress, guilt and even depression as well as selfcontrol over other negative symptoms (Manita et al., 2019), unmanaged stress can have a major impact on health. physical and mental well-being that lead to various diseases such as depression (Clemente \& Hezomi, 2016). Results This study is in line with previous research which found that there was a negative relationship between stress and well-being (Manita et al., 2019). Another study also found that there is a negative and significant role of Subjective Wellbeing (SWB) on stress, where if the SWB is high, the stress will be low, and vice versa if the SWB is low, the stress will be high. the percentage of stress affecting well-being is $29.2 \%$ and $70.8 \%$ is influenced by other factors (Wijaya, 2017).

\section{CONCLUSION}

The results show that the characteristics of pregnant women (mother's age, gestational age, parity and stress of pregnant women affect the psychological well-being of pregnant women. From this study, it is expected that there will be a role for health workers, families to provide support to pregnant women, pregnant women are expected to apply management stress to improve coping with stress during pregnancy.Further research is needed to see the role of husbands in emotional support to pregnant women. 


\section{REFERENCES}

Abdollahi, F., Agajani-Delavar, M., Zarghami, M., \& Lye, M. S. (2016). Postpartum mental health in first-time mothers: A cohort study. Iranian Journal of Psychiatry and Behavioral Sciences, 10(1), 1-7. https://doi.org/10.17795/ijpbs-426

Arisanti, A. Z. (2021). DAMPAK PSIKOLOGIS IBU HAMIL PADA MASA PANDEMI COVID-19 Literature Review. Jurnal Sehat Masada , XV, 241-250.

Brunton, R., Simpson, N., \& Dryer, R. (2020). Pregnancy-related anxiety, perceived parental selfefficacy and the influence of parity and age. International Journal of Environmental Research and Public Health, 17(18), 1-17. https://doi.org/10.3390/ijerph17186709

Budiarti, E., \& Hanoum, M. (2019). Koping Stres dan Dukungan Keluarga terhadap Kesejahteraan Psikologis Orang Tua yang Memiliki Anak Berkebutuhan Khusus. SOUL: Jurnal Pemikiran Dan ..., 44-61. http://jurnal.unismabekasi.ac.id/index.php/soul/article/view/2158

Choiriyah, D. W. (2016). Depresi Pada Ibu dan Pengaruhnya dalam Perilaku Pengasuhan. Jurnal Proyeksi, 11(1), 65-76.

Clemente, M., \& Hezomi, H. (2016). Stress and Psychological Well-being: An Explanatory Study of the Iranian Female Adolescents. Journal of Child and Adolescent Behaviour, 04(01), 15. https://doi.org/10.4172/2375-4494.1000282

Holopainen, A., \& Hakulinen, T. (2019). Easing the transition to parenthood: The importance of perinatal and postnatal mental health for mothers and fathers. JBI Database of Systematic Reviews and Implementation Reports, 17(9), 1727-1728. https://doi.org/10.11124/JBISRIR-D-19-00244

Leonard, S. (2020). Wife, Inc.: The Business of Marriage in the Twenty-First Century. books.google.com. https://books.google.com/books?hl=en\&lr=\&id=AO5DwAAQBAJ\&oi=fnd\&pg=PA1\&dq=teen+marriage\&ots=aAr06Y20wt\&sig=PtZr6cd yjrM0k72saPfOP2gvv04

Lestari, S., \& Widyawati, Y. (2016). Gambaran parenting stress dan coping stress pada ibu yang memiliki anak kembar. Jurnal Psikogenesis. http://academicjournal.yarsi.ac.id/index.php/Jurnal-Online-Psikogenesis/article/view/516

López-Morales, H., del Valle, M. V., Canet-Juric, L., Andrés, M. L., Galli, J. I., Poó, F., \& Urquijo, S. (2021). Mental health of pregnant women during the COVID-19 pandemic: A longitudinal study. Psychiatry Research, 295(3), 57-72. https://doi.org/10.1016/j.psychres.2020.113567

Mahmudah, M., Yaunin, Y., \& Lestari, Y. (2016). Faktor-faktor yang berhubungan dengan perilaku seksual remaja di Kota Padang. Jurnal Kesehatan Andalas. http://jurnal.fk.unand.ac.id/index.php/jka/article/view/538

Manita, E., Mawarpury, M., Khairani, M., \& Sari, K. (2019). Hubungan Stres dan Kesejahteraan (Well-being) dengan Moderasi Kebersyukuran. Gadjah Mada Journal of Psychology (GamaJoP), 5(2), 178. https://doi.org/10.22146/gamajop.50121

Marta Bassi. (2017). Psychological well-being and depression from pregnancy to postpartum 
among primiparous and multiparous women.

Mofrad, H. A., Khalatbari, J., \& ... (2021). ... Conflicts and Affective Security with Perceived Stress and Pregnancy Worries and Biological Indexes with the Mediation of Psychological Wellbeing in Pregnant .... In Women ... womenstudy.ihcs.ac.ir. https://womenstudy.ihcs.ac.ir/article_6425_3e9e942a797ca3f982541f2d306baafe.pdf

Mubarak, W. I., Indrawati, L., \& Susanto, J. (2015). Buku Ajar Ilmu Keperawatan Dasar 1 (A. Suslia (ed.)). Salemba Medika.

Nabit, Y. P., Keraf, M. K. P. A., \& Anakaka, D. L. (2019). Strategi Coping Stres pada Ibu Single Parent Pasca Ditinggal Suami Merantau. Journal of Health and Behavioral Science, 1(4), 241-261.

Octaviani, M., Herawati, T., \& Tyas, F. P. S. (2018). Stres, Strategi Koping dan Kesejahteraan Subjektif pada Keluarga Orang Tua Tunggal. In Jurnal Ilmu Keluarga \& .... journal.ipb.ac.id. http://journal.ipb.ac.id/index.php/jikk/article/download/20380/15852

Parfitt, Y., \& Ayers, S. (2014). Transition to parenthood and mental health in first-time parents. Infant Mental Health Journal, 35(3), 263-273. https://doi.org/10.1002/imhj.21443

Ramluggun, P., Kamara, A., \& Anjoyeb, M. (2020). Postnatal depression in fathers: a quiet struggle? British Journal of Mental Health Nursing, 9(4), 1-8. https://doi.org/10.12968/bjmh.2019.0042

Sanadi, A. B., Anuchithra, S., \& Radhakrishnan, G. (2016). Mental Health and Wellbeing during Transition to Parenthood. Asian Journal of Nursing Education and Research, 6(1), 109. https://doi.org/10.5958/2349-2996.2016.00023.9

Saxbe, D. (2018). The transition to parenthood as a critical window for adult health. American Psychologist, 73(9), 1190-1200. https://doi.org/10.1037/amp0000376

Sesillia, L. (2020). Kesejahteraan psikologis (psychological well-being) pada masyarakat miskin. Universitas Islam Negeri sultan Syarif Kasim Riau.

Sulistiawati, I., \& Pratiwi, C. S. (2021). Psychological Disorder of Women < 18 Years Old with Early-Age Marriage. 2(3), 177-189. https://doi.org/10.31101/ijhst.v2i3.1969

Wijaya, E. (2017). Peranan Humor terhadap Stres dengan Subjective Well Being (SWB) sebagai Mediator pada Dewasa Awal. Jurnal Muara Ilmu Sosial, Humaniora, Dan Seni, 1(1), 353. https://doi.org/10.24912/jmishumsen.v1i1.377

Zhou, Y., Shi, H., Liu, Z., Peng, S., Wang, R., Qi, L., Li, Z., Yang, J., Ren, Y., Song, X., Zeng, L., Qian, W., \& Zhang, X. (2020). The prevalence of psychiatric symptoms of pregnant and non-pregnant women during the COVID-19 epidemic. Translational Psychiatry, 10(1). https://doi.org/10.1038/s41398-020-01006-X 